\title{
Readmissions to a Pediatric Ward: An Eleven-Year Experience in a Portuguese Hospital
}

\section{Reinternamentos numa Enfermaria de Pediatria: A Experiência de Onze Anos de um Hospital Português}

\author{
Joana SOUSA MARTINS ${ }^{1}{ }^{1}$, Rita SOUSA ${ }^{1}$, Joana MATIAS ${ }^{1}$, Paulo CALHAU ${ }^{1}$ \\ Acta Med Port 2022 Jul-Aug;35(7-8):540-549 - https://doi.org/10.20344/amp.17011
}

\section{ABSTRACT}

Introduction: Pediatric readmissions have received increased attention in the past few years. Distinguishing between planned and unplanned readmissions and between preventable and unpreventable ones constitutes an important target to better understand this thematic. The aim of this study was to analyze the readmission rate and characterize the population readmitted within a 30 -day period after discharge in the pediatric ward of a level II hospital.

Material and Methods: Observational retrospective single center study of the pediatric patients who were discharged from a level II hospital, between 2009 and 2019, and had at least one readmission within 30 days after discharge. Clinical and demographic data were obtained from the analysis of the patient's medical records. We considered as potentially preventable all the unplanned readmissions that were related with the index admission.

Results: From the 6879 admissions during the study period, $4.8 \%$ resulted in readmissions within the next 30 days. Excluding the planned readmissions, the seven, 15 and 30 -day readmission rates were respectively $1.7 \%, 2.7 \%$ and $3.9 \%$. Most of the unplanned readmissions $(77 \%)$ were considered as potentially preventable. Patients reevaluated in the Pediatric Day Hospital after discharge had shorter intervals to readmission. Readmissions due to decompensation of chronic disease were more likely related with the index admission. Patients with chronic disease, as well as patients with neurological impairment were more likely to have multiple readmissions.

Conclusion: We found a low overall readmission rate, but a higher percentage of potentially preventable readmissions, when compared with the available literature.

Keywords: Child; Hospitals, Pediatric; Patient Discharge; Patient Readmission

\section{RESUMO}

Introdução: Nos últimos anos, os reinternamentos pediátricos têm sido alvo de atenção crescente. Distinguir reinternamentos programados de não programados, e os que podem ou não ser evitados constituem aspetos importantes para a melhor compreensão desta temática. O objetivo deste estudo foi analisar a taxa de reinternamentos e caracterizar a população reinternada até 30 dias após a alta numa enfermaria de Pediatria de um hospital de nível II.

Material e Métodos: Estudo observacional retrospetivo dos doentes com alta da enfermaria de Pediatria de um hospital de nível II, entre 2009 e 2019, e que tiveram pelo menos um reinternamento até 30 dias após a alta. Dados clínicos e demográficos foram obtidos a partir da análise dos processos clínicos. Considerámos potencialmente evitáveis os reinternamentos não programados relacionadas com o internamento índex.

Resultados: Das 6879 admissões durante o período de estudo, 4,8\% resultaram em reinternamento até 30 dias. Excluindo os reinternamentos programados, a taxa de reinternamento até sete, 15 e 30 dias foi, respetivamente, $1,7 \%, 2,7 \%$ e $3,9 \%$. A maioria dos reinternamentos não programadas $(77 \%)$ foi considerada potencialmente evitável. Os doentes reavaliados em Hospital de Dia após a alta apresentaram um menor intervalo até ao reinternamento. Os reinternamentos devido à descompensação de doença crónica apresentaram maior probabilidade de estarem relacionados com o internamento índex. Doentes com doença crónica e com compromisso neurológico apresentaram maior probabilidade de terem múltiplos reinternamentos.

Conclusão: Em comparação com a literatura disponível, foi identificada uma baixa taxa global de reinternamentos, mas uma percentagem superior de reinternamentos potencialmente evitáveis.

Palavras-chave: Alta do Doente; Criança; Hospitais Pediátricos; Readmissão do Doente

\section{INTRODUCTION}

The impact of hospital readmissions has been an object of study for the last six decades, especially in the adult population. ${ }^{1}$ Although pediatric patients have, in general, lower readmission rates than adults, a growing attention has been given to this subject in the past few years. ${ }^{1-3}$ However, the information available on pediatric readmissions remains relatively sparse and derives mainly from studies on specific age groups or medical conditions. ${ }^{3-5}$

A hospital readmission can be defined as a new admission within a certain period after discharge, from seven days to one year. The most common definition considers a 30-day period after discharge. Readmissions within 15days of a previous discharge are usually considered early readmissions. ${ }^{6,7}$ In children, readmissions rates vary among different studies, but are usually low, with about $6.5 \%$ of hospitalized children experiencing an unplanned readmission to an acute care hospital within 30-days. ${ }^{7,8}$

In adults, it has been established that high hospital readmission rates are associated with an increase in healthcare costs, psychosocial burden and higher hospital

1. Serviço de Pediatria. Hospital Garcia de Orta. Almada. Portugal.

$\triangle$ Autor correspondente: Joana Sousa Martins. joanam1@campus.ul.pt

Recebido/Received: 16/08/2021 - Aceite/Accepted: 03/11/2021 - Publicado Online/Published Online: 23/02/2022 - Publicado/Published: 01/07/2022 Copyright $(\odot)$ Ordem dos Médicos 2022 
mortality rates. ${ }^{9}$ Therefore, readmission rates are increasingly being used as a measure of healthcare quality, assuming they may result from substandard quality of care delivered during the initial hospital stay, such as incomplete treatment of the underlying condition or inadequate discharge planning. ${ }^{3,8,10}$ However, it is also recognized that many other factors before and after the hospitalization, which are beyond the hospital's direct control, contribute to the risk of readmission. Therefore, using readmission rates as a single quality measure remains controversial. ${ }^{11,12}$ On the other hand, and for some medical conditions, high readmission rates can result from low mortality rates and a good access to hospital care. ${ }^{11}$

Hospital readmissions in children also constitute a complex event influenced by multiple factors, including not only the hospital care during the index admission, but also factors associated with the patient and his family, such as the presence of an underlying chronic disease and the socioeconomic resources, and external factors such as the access to primary medical care and social support. $6,10,13$ Known risk factors for readmission in children include the presence of a chronic health condition, complex care needs and a fragile social support network. ${ }^{14,15}$

The experience of worsening health after discharge and returning for another hospitalization is generally undesirable and disruptive for both the child and the family.,12 As such, reducing readmission rates not only contributes to decreasing healthcare costs, but can also influence the children's well-being. To accomplish this goal, multiple interacting factors must work efficiently, including the process of discharge, family education, social support system and primary health care in the community. ${ }^{16}$

Some readmissions are expected, necessary and unpreventable, whereas others are not. Distinguishing between planned and unplanned readmissions and between preventable and unpreventable ones in children constitutes an important target in order to better understand this subject. ${ }^{1,15}$

The main aim of this study was to analyze the readmission rate and characterize the population readmitted within a 30-day period after discharge in the pediatric ward of a level II hospital, during an eleven-year period. A secondary aim was to identify possible differences in the time to readmission in groups with different clinical and demographical variables and to find a possible association between these variables and the occurrence of multiple readmissions and readmissions associated with the index admission. The authors expect that studying this population might help to improve clinical practice and reduce pediatric hospital readmissions.

\section{MATERIAL AND METHODS}

The authors performed an observational retrospective study of the pediatric patients (aged zero to 17 years and 365 days) who were discharged from our hospital's pediatric ward between the $1^{\text {st }}$ January 2009 and the $31^{\text {st }}$ December
2019 and had at least one readmission within that period and up to the $31^{\text {st }}$ January 2020 . We considered a readmission when the patient was readmitted to the pediatric ward until 30 days after the discharge from the index admission (original admission). Additional admissions within 30 days were not considered as readmissions or index admissions. An additional admission after 30 days was considered as a new index admission.

The pediatric department where the study was carried out is part of a level II hospital located in the Greater Lisbon area. It is mainly a general pediatric department, but is also a reference in Neonatology and Pediatric Neurology. It is a department that has a very active day hospital and privileges ambulatory care, working in great proximity with both primary care and long-term care units.

Data was obtained from the analysis of the electronic medical records of patients. We analyzed demographic data (sex, age at index admission, area of residence, assignment of a family doctor) and data from the index admission and the readmission (length of stay, primary diagnosis - categorized by the International Statistical Classification of Diseases and Related Health Problems 10th Revision, ICD-10 -, existence of an underlying chronic medical condition, destination after discharge, time between discharge and readmission, readmission planning and, if so, with what purpose). The reasons for readmission were classified as related or unrelated with the index admission and, in the ones related with the index admission, were further categorized as worsening or recurrence of symptoms, or complication of procedures. We considered all the non-programmed readmissions that were related to the index admission as potentially preventable. We defined as a complex chronic disease any medical condition for which it is reasonable to expect a duration of at least 12 months (except in the case of death) and which affects several different systems or an organ in a sufficiently severe manner to require specialized pediatric care and probably some period of admission to a tertiary medical center. ${ }^{17}$ We considered as neurological impairment the presence of intellectual disability, limitations in mobility and/or communication difficulties. A permanent catheter was considered as any central vascular line or ventriculoperitoneal or atrial shunt.

The authors performed a descriptive analysis to characterize the studied population and a statistical analysis using independent $t$-student test (after applying a normality test) to compare means of readmission times between groups of variables and chi-square test to access possible associations between categorical variables, calculating the odds ratio for the statistically significant associations. The statistical work was carried out in SPSS ${ }^{\circledR}$ Statistics 24 (IBM Corp., 2016, United States of America); $p$ values of 0.05 were considered statistically significant. The study was approved by the hospital's Ethics Committee. The need for informed consent was waived as this was a retrospective non-interventional study. 


\section{RESULTS}

Characterization of the studied population (Table 1; $n$ = 267)

During the study period, there were a total of $6879 \mathrm{ad}-$ missions in our pediatric ward; $333(4.8 \%)$ were followed by a readmission within 30 days of discharge. These 333 readmissions occurred in 267 patients, meaning that 28 patients $(10.5 \%)$ had two or more readmissions. From the total of patients readmitted, 138 were male and 129 were female. The mean age at the index admission was $4 \pm 5$ years (range from 0 to 17 years). About half of the patients were younger than one year old $(45.7 \%)$ and more than two thirds of patients $(68.9 \%)$ were younger than five years of age at the index admission. About half of the patients (46.4\%) had an underlying chronic disease, the most frequent being nervous system diseases $(27.4 \%)$, congenital malformations (26.6\%) and hematologic diseases (12.1\%). Around $91 \%$ of chronic diseases were complex chronic diseases. About $10 \%$ of patients had medical devices and approximately $23 \%$ had some degree of neurological impairment (cognitive and/or motor impairment). Most patients $(77.1 \%)$ lived in the hospital area and had an assigned family doctor $(77.2 \%)$.

\section{Characterization of the index admissions (Table 2; $\mathbf{n}=$ 333)}

Most patients concerning index admissions (60.9\%) were admitted through the pediatric emergency department. There were several primary diagnoses, the most frequent ones belonging to the respiratory system group (23.1\%). About $15.6 \%$ of index admissions involved surgical intervention. The duration of the index admission was $9 \pm 16$ days (range from 0 to 175 days). The destination after discharge was mostly to the patient's home $(92.8 \%$ four of these patients with home support). About one third of discharges $(33.9 \%)$ were evaluated in the pediatric day hospital. Most of the admissions (70.9\%) were referred to pediatric ambulatory hospital care at discharge.

Characterization of the readmissions (Table 3; $n=333$ )

There was an average interval time of $11 \pm 9$ days between the index admission discharge and the readmission (range from zero to 30 days). Most of the readmissions occurred until 15 days after discharge $(68.5 \%)$.

The length of stay in the readmission was $10 \pm 42$ days (range from zero to 746 days). The total length of hospital stay (index admission plus readmission) was $18 \pm 45$ days (range of one to 757 days).

Most patients had an unplanned readmission (81.4\%) and were admitted through the pediatric emergency department $(60 \%)$. Regarding the planned readmissions, most $(79.3 \%)$ were for medical or surgical treatment or diagnostic assessment. The most frequent primary diagnosis, excluding the group of symptoms and signs not elsewhere classified, were the ones belonging to the respiratory and nervous system groups ( $24 \%$ and $12.3 \%$, respectively).

Concerning the unplanned readmissions, 209 (77.1\%)
Table 1 - Demographic and clinical characterization of the studied population $(n=267)$

\begin{tabular}{|c|c|}
\hline & n (\%) \\
\hline \multicolumn{2}{|l|}{ Sex } \\
\hline Male & $138(51.7)$ \\
\hline Female & $129(48.3)$ \\
\hline \multicolumn{2}{|c|}{ Age (years) } \\
\hline$<1$ & $122(45.7)$ \\
\hline $1-4$ & $62(23.2)$ \\
\hline $5-9$ & $40(15.0)$ \\
\hline $10-14$ & $23(8.6)$ \\
\hline$\geq 15$ & $20(7.5)$ \\
\hline
\end{tabular}

Chronic disease

No

$143(53.6)$

Yes

$124(46.4)$

Complex chronic disease

$113(91.1)$

Non-complex chronic disease

Nervous system

$34(27.4)$

Congenital malformations

$33(26.7)$

Hematologic

$15(12.1)$

Perinatal period

$15(12.1)$

Respiratory system

7 (5.6)

Endocrine and metabolic

5 (4.0)

Digestive system

5 (4.0)

Neoplasms

$4(3.2)$

Musculoskeletal system and connective tissue

3 (2.4)

Mental and behavioral

Genitourinary system

Neurological impairment

Yes

$62(23.2)$

Motor

$26(41.9)$

Cognitive

7 (11.3)

Both

No

$205(76.8)$

Medical devices

Yes

Permanent catheter

Gastrostomy

4 (15.4)

Tracheostomy

2 (7.7)

Other

No

\section{Residence}

Hospital's referral area

206 (77.2)

Outside hospital's referral area

Family physician

Yes

$206(77.2)$

No

Unknown 


\section{Source of admission}

Pediatric emergency department

Pediatric outpatient care

Neonatal and pediatric intensive unit

Other outpatient care

Other hospital

Pediatric day hospital

Other

Surgery

Yes

No

Primary diagnosis (ICD-10)

Respiratory system

Symptoms and signs not elsewhere classified

$47(14.1)$

Nervous system

Hematologic

Perinatal period

Congenital malformations

Neoplasms

Infectious

Circulatory system

Digestive system

Musculoskeletal system and connective tissue

Skin and subcutaneous tissue

Genitourinary system

Injury and poisoning

Ear and mastoid process

Endocrine and metabolic

Eye and adnexa

External causes of morbidity and mortality

Mental and behavioral

Factors influencing health status and contact with healthcare services

Length of stay (days)

$0-2$

$3-7$

$8-14$

$\geq 15$

Destination after discharge

Home

Home with outpatient support

Inpatient institution

Other hospital

Evaluation in Pediatric Day Hospital after discharge

Yes

No

Referral to pediatric ambulatory hospital care 
were considered by the authors to be related with the index admission and most of them occurred after clinical worsening or symptomatic recurrence $(90.4 \%)$. The remaining unplanned readmissions related with the index admission (9.6\%) happened due to complications of procedures performed in the index admission.

Considering the overall number of admissions in the study period, which was 6879 , the overall 30 -day readmission rate in our study was $4.8 \%(n=333)$. When excluding the programmed readmissions, the seven, 15 and 30-day readmission rates were, respectively, $1.7 \%(n=119), 2.7 \%$ $(n=186)$ and $3.9 \%(n=267)$. As for the potentially preventable readmissions only, the readmission rate was $3 \%$ ( $n=$ 209).

\section{Statistical analysis (Tables 4, 5 and 6)}

There were no statistically significant differences between time to readmission and sex, assignment of a family physician or presence of chronic disease.

Planned and unplanned readmissions had also similar

Table 3 - Characterization of the readmissions $(n=333)$ (initial section)

\begin{tabular}{|c|c|}
\hline & n (\%) \\
\hline \multicolumn{2}{|l|}{ Origin of readmission } \\
\hline Pediatric emergency department & $200(60.0)$ \\
\hline Pediatric day hospital & $37(11.1)$ \\
\hline Other specialty outpatient care & $26(7.8)$ \\
\hline Pediatric outpatient care & $25(7.5)$ \\
\hline Other hospital & $25(7.5)$ \\
\hline Neonatal and pediatric intensive unit & $8(2.4)$ \\
\hline Other & $12(3.6)$ \\
\hline \multicolumn{2}{|l|}{ Type of readmission } \\
\hline Unplanned & $271(81.4)$ \\
\hline Planned & $62(18.6)$ \\
\hline Medical treatment & $18(29.0)$ \\
\hline Surgical treatment & $21(34.0)$ \\
\hline Diagnostic investigation & $17(27.4)$ \\
\hline Caregiver's rest & $3(4.8)$ \\
\hline Other & $3(4.8)$ \\
\hline \multicolumn{2}{|l|}{ Primary diagnosis } \\
\hline Respiratory system & $80(24.0)$ \\
\hline Symptoms and signs not elsewhere classified & $68(20.4)$ \\
\hline Nervous system & $41(12.3)$ \\
\hline Hematologic & $27(8.1)$ \\
\hline Congenital malformations & $18(5.4)$ \\
\hline Musculoskeletal system and connective tissue & $14(4.2)$ \\
\hline Skin and subcutaneous tissue & $11(3.3)$ \\
\hline Digestive system & $10(3.0)$ \\
\hline Injury and poisoning & $9(2.7)$ \\
\hline Circulatory system & $9(2.7)$ \\
\hline Genitourinary system & $8(2.4)$ \\
\hline Infectious & $8(2.4)$ \\
\hline Neoplasms & $7(2.1)$ \\
\hline Perinatal period & $7(2.1)$ \\
\hline Factors influencing health status and contact with healthcare services & $4(1.2)$ \\
\hline Endocrine and metabolic & $4(1.2)$ \\
\hline Ear and mastoid process & $3(0.9)$ \\
\hline Eye and adnexa & $2(0.6)$ \\
\hline External causes of morbidity and mortality & $2(0.6)$ \\
\hline Mental and behavioral & $1(0.3)$ \\
\hline
\end{tabular}


Table 3 - Characterization of the readmissions $(n=333)$ (final section)

\section{Length of stay (days)}

$0-2$

$3-7$

$8-14$

$\geq 15$

Interval from discharge to readmission (total readmissions)

Up to 7 days

Up to 15 days

Interval from discharge to readmission (unplanned readmissions)

Up to 7 days

Up to 15 days

Relation to the index admission (unplanned readmissions)

Unrelated

Related (potentially preventable)

Clinical worsening or recurrence of symptoms

Complication of procedures

- Surgical wound infection $(n=6)$

- CSF fistula $(n=6)$

- Post-surgery meningitis $(n=5)$

- Urinary tract infection after cystography $(n=1)$

- Post-catheterization hematuria $(n=1)$

- Incarceration of PEG ( $n=1)$

Chronic disease (unplanned readmissions)

No

Yes

Readmission due to decompensation of chronic disease

intervals of time to readmission. Readmissions that were considered to be related with the index admission had shorter times to readmission, but without statistical significance (11 vs 13 days, $p$ value $=0.10$ ). When the patients were assessed in the pediatric day hospital after discharge from the index admission, the time to readmission was significantly shorter (9 vs 12 days, $t$-test - 2.662; gl 331; $p$ value $=0.008$ ).

In unplanned readmissions, there was no statistically significant difference between the age groups and the association with the index admission.

When there was an underlying chronic disease, we found that the presence of decompensation of chronic disease was more frequent in the readmissions related with the index admission ( $p$ value $<0.001$ ) with an odds ratio of 6.0 (95\% IC, 2.7 to 13.0$)$.

Patients with chronic disease were more likely to have multiple readmissions ( $p$ value $<0.001$ ) with an odds ratio of 11.8 (95\% IC, 3.5 to 40.1$)$ as well as patients with neurological impairment, $(p$ value $=0.002$ ) with an odds ratio of 3.4 (95\% IC, 1.5 to 7.5$)$. The same was not demonstrated in the group with medical devices.

\section{DISCUSSION}

As far as we know, and even though there are previous studies on readmissions to pediatric emergency departments, ${ }^{18-20}$ this is the first Portuguese study on readmissions to a pediatric ward, The all-cause 30 -day readmission rate in our study was $4.8 \%$, which is similar to the results of Feudtner et $\mathrm{a}^{14}$ and lower than the $6.1 \%$ readmission rate obtained by Sills et al. ${ }^{21}$ When excluding the planned readmissions, the seven, 15 and 30-day readmission rates were respectively $1.7 \%, 2.7 \%$ and $3.9 \%$. These numbers are lower than what was reported in most pediatric studies. The largest study on pediatric readmissions to date is the one developed by Berry et al, involving 72 children's hospitals and more than 568000 readmissions. These authors found an overall 30 day unplanned readmission rate of $6.5 \%,{ }^{7}$ the same rate reported by Toomey et al. ${ }^{8}$ In 2011, Gay et al reported a 15-day readmission rate of $8.4 \% 5$ and in a different study four years later, found all-cause readmission rates at seven, 15 and 30 days of $5 \%, 8.7 \%$, and $13.3 \%$, respectively. ${ }^{6}$ The most similar results to our study were those reported by Wallace et al in 2015 and by Pérez et al in 2019, with an overall 30 -day unplanned readmission rate of $3.1 \%$ and 


Sex $(n=333)$
Male
Female

$$
11 \pm 9
$$

Chronic disease $(n=333)$

$$
\text { Yes }
$$$$
11 \pm 9
$$

$$
\text { No }
$$$$
12 \pm 8
$$

Family physician $(n=323)$

Planned readmission $(n=333)$

Readmission related with index admission/ potentially preventable $(n=271)$

Surgery in index admission $(n=333)$

$$
\text { Yes }
$$$$
13 \pm 9
$$

No

$$
\begin{aligned}
& 12 \pm 9 \\
& 11 \pm 9
\end{aligned}
$$

Neurologic impairment $(n=333)$

$$
\text { Yes }
$$

No

Presence of medical devices $(n=333)$

Yes

$11 \pm 9$

$$
\text { No }
$$

$$
10 \pm 9
$$

Assessment in pediatric day hospital after index admission discharge $(n=333)$

* Independent $t$-student test

\section{$4.1 \%$, respectively. ${ }^{22,23}$}

As for Portuguese references, a recent national study on general hospital readmissions found an overall 30-day readmission rate of $6.8 \%$, with lower rates in children and young people $(2.6 \%$ in zero to 14 years and $3.8 \%$ in 15 to 24 years), which is also consistent with our results. ${ }^{9}$

One possible explanation for our lower readmission rates, almost half when compared to most studies in the pediatric population, might be the fact that our study was carried out in a pediatric ward of a level II hospital, as opposed to most studies presented, which involved children's hospitals, which are mostly level III. These hospitals usually have a population with a higher degree of medical complexity, who are prone to more readmissions.

One could speculate that the fact that our department privileges ambulatory care and, therefore, usually discharges children as early as possible, would be associated with a high rate of readmissions. However, we demonstrated this wasn't the case. In the light of these results, we could say that our department's general approach is fairly safe.

In the study of readmissions, many authors highlight the importance of primarily distinguishing between planned and unplanned readmissions, and most exclude planned readmissions from their analyses. ${ }^{24}$ We found a percentage of planned readmissions of $18.6 \%$, mostly for medical or surgical treatment or diagnostic investigation. There weren't any measures to reduce this kind of readmissions and they were often helpful, beneficial and related with the prevention of further health issues. ${ }^{25}$

After distinguishing planned from unplanned readmissions, it is critical, although challenging, to differentiate preventable from unpreventable ones in order to better design methods to reduce readmission rates and to possibly use them as a quality metric. ${ }^{6,15}$ Sometimes, even though it is assumed that all unplanned readmissions are preventable, one can't plan measures to prevent readmissions in which the cause isn't related with the index admission. ${ }^{25}$ In our study, we assumed as potentially preventable every unplanned readmission that was related with the index admission. Most of the unplanned readmissions (77\%, corresponding to $63 \%$ of all readmissions and $3 \%$ of total hospital admissions) were related with the index admission 
Table 5 - Comparison between demographic and clinical variables and the association with the index admission (unplanned readmissions)

\begin{tabular}{|c|c|c|c|c|}
\hline & $\begin{array}{l}\text { Readmission related } \\
\text { with index admission / } \\
\text { potentially preventable }\end{array}$ & $\begin{array}{c}\text { Readmission } \\
\text { non-related with } \\
\text { index admission }\end{array}$ & $p$ value* & Odds ratio \\
\hline Age group $(n=271)$ & $(n=209)$ & $(n=62)$ & \multirow{6}{*}{0.139} & \multirow{9}{*}{$\begin{array}{c}6.0 \\
(95 \% \text { IC, } 2.7 \text { to 13.0) }\end{array}$} \\
\hline < 1 year $(n=109)$ & $76(70 \%)$ & $33(30 \%)$ & & \\
\hline $1-4$ years $(n=76)$ & $60(65 \%)$ & $16(35 \%)$ & & \\
\hline $5-9$ years $(n=46)$ & $40(87 \%)$ & $6(13 \%)$ & & \\
\hline $10-14$ years $(n=25)$ & $20(80 \%)$ & $5(20 \%)$ & & \\
\hline$\geq 15$ years $(n=15)$ & $13(87 \%)$ & $2(13 \%)$ & & \\
\hline Decompensation of chronic disease $(n=158)^{\#}$ & $(n=117)$ & $(n=41)$ & \multirow{3}{*}{$<0.001$} & \\
\hline Yes $(n=99)$ & $86(87 \%)$ & $13(13 \%)$ & & \\
\hline No $(n=59)$ & $31(53 \%)$ & $28(47 \%)$ & & \\
\hline Surgery in index admission $(n=271)$ & $(n=209)$ & $(n=62)$ & \multirow{3}{*}{0.144} & \\
\hline Yes $(n=37)$ & $32(86 \%)$ & $5(14 \%)$ & & \\
\hline No $(n=234)$ & $177(76 \%)$ & $57(24 \%)$ & & \\
\hline Neurologic impairment $(n=271)$ & $(n=209)$ & $(n=62)$ & \multirow{3}{*}{0.603} & \\
\hline Yes $(n=86)$ & $68(79 \%)$ & $18(21 \%)$ & & \\
\hline No $(n=185)$ & $141(76 \%)$ & $44(24 \%)$ & & \\
\hline Presence of medical devices $(n=271)$ & $(n=209)$ & $(n=62)$ & \multirow{3}{*}{0.980} & \\
\hline Yes $(n=26)$ & $20(77 \%)$ & $6(23 \%)$ & & \\
\hline No $(n=245)$ & $189(77 \%)$ & $56(23 \%)$ & & \\
\hline
\end{tabular}

*: Chi-square test; \#: Number of unplanned readmissions in patients with chronic disease

Table 6 - Comparison between patients with a single readmission and patients with multiple readmissions $(\mathrm{n}=267)$

\begin{tabular}{|c|c|c|c|c|}
\hline & $\begin{array}{l}\text { Patients with multiple } \\
\text { readmissions }\end{array}$ & $\begin{array}{l}\text { Patients with a single } \\
\text { readmission }\end{array}$ & p value* & Odds ratio \\
\hline Chronic disease & $(n=28)$ & $(n=239)$ & \multirow{3}{*}{$<0.001$} & \multirow{3}{*}{$\begin{array}{c}11.8 \\
(95 \% \text { IC, } 3.5 \text { to } 40.1)\end{array}$} \\
\hline Yes $(n=124)$ & $25(20 \%)$ & $99(80 \%)$ & & \\
\hline No $(n=143)$ & $3(2 \%)$ & $140(98 \%)$ & & \\
\hline Presence of medical devices & $(n=28)$ & $(n=239)$ & \multirow{3}{*}{0.126} & \\
\hline Yes $(n=26)$ & $5(19 \%)$ & $21(81 \%)$ & & \\
\hline No $(n=241)$ & $23(10 \%)$ & $218(90 \%)$ & & \\
\hline Neurological impairment & $(n=28)$ & $(n=239)$ & \multirow{3}{*}{0.002} & \multirow{3}{*}{$\begin{array}{c}3.4 \\
(95 \% \text { IC, } 1.5 \text { to } 7.5)\end{array}$} \\
\hline Yes $(n=62)$ & $13(21 \%)$ & $49(79 \%)$ & & \\
\hline No $(n=205)$ & $15(7 \%)$ & $190(93 \%)$ & & \\
\hline
\end{tabular}

*: Chi-square test

and thus deemed as potentially preventable. When compared with most studies, which found rates of preventable readmissions ranging from $20 \%$ to $30 \%,{ }^{3,8,23}$ we obtained a higher percentage of potentially preventable readmissions which can, in part, be explained by the different methodologies used to assess preventability.

Several authors perceived that, preventable readmissions, or readmissions related with the index admission, occurred earlier after hospital discharge than unpreventable or unrelated ones, ${ }^{8}$ which was also the case in our study, although without statistical significance.

To the best of our knowledge, our study was the first to assess the interference of clinical reevaluation at a Pediatric Day Hospital after discharge on readmissions. We found that when patients were evaluated at the Pediatric Day
Hospital, the time to readmission was significantly shorter. We might argue that this happened because pediatricians schedule children with more severe disease or with clinical conditions not completely resolved after discharge or with the potential to regress or stagnate for evaluation at the day hospital. These children usually require close follow up shortly after discharge and sometimes it is not possible to maintain care exclusively ambulatory. A possible premature discharge of these patients is also a possibility to consider but was not further investigated in this study.

Several studies reported on the impact of chronic diseases in pediatric readmissions. Markham et $a^{4}{ }^{4}$ reported that $79 \%$ of readmissions were in patients with an underlying chronic illness, which was similar to the percentage presented by Gay et al..$^{5}$ Comparably, in our study, about half 
the readmissions (56.2\%) occurred in patients with an underlying chronic disease, almost all being considered complex chronic diseases. We also found that readmissions due to decompensation of a chronic disease were more likely related with the index admission and therefore, more likely to be preventable, thus differing from the study of Toomey et al which found no relation between these variables. ${ }^{8}$ In our study, we also found that children with a chronic disease and children with neurological impairment were more likely to have multiple readmissions. Our results support the idea that the presence of chronic disease in pediatric patients may have a significant influence on readmissions.

Although in our study there was a significant dispersion in groups of diagnoses in both the index admission and the readmission, the most frequent diagnoses in the readmission were respiratory and nervous system diseases. The predominance of respiratory diseases is expected as they are some of the most common diseases in childhood, and thus some of the most common diseases that cause readmissions. The prevalence of nervous system diseases is, in part, explained by the existence of a pediatric neurodevelopment center in our hospital, where many children with nervous system conditions are followed. These kinds of conditions may imply a higher rate of readmissions, since they are mainly chronic diseases, with many associated with cognitive or motor impairment and some with the need for the support of medical devices.

Many authors contest the use of readmission rates as an acceptable quality measure of hospital care and claim that it should only be used as a marker of healthcare use. It is argued that we need more research to better determine the proportion of readmissions that are due to poor hospital quality of care versus other reasons for readmissions (such as complex social environments and difficulties in access to primary ambulatory care) and how many are preventable. Until then, one should not consider pediatric readmission rates as a quality indicator of single hospitals but as a quality indicator of the entire healthcare system..$^{8,16,25-28}$

Whether or not they should be considered a suitable measure of hospital quality, knowledge of pediatric hospital readmission rates and the characterization of this population is essential to help reduce preventable readmissions. In particular, parental perception of the child's health and discharge conditions has been associated with the risk of readmission, with both parents and healthcare care providers identifying communication difficulties and lack of shared understanding as potential causes for readmission. ${ }^{29-32}$ Optimization of discharge planning, including family education and care coordination with ambulatory and outpatient providers is essential, especially for children with complex medical needs. ${ }^{30}$ Some authors suggest an optimized process of discharge, including a team with specialized knowledge of the child's condition to assume responsibility for the inpatient-to-outpatient transition and that offers ongoing support to the family following discharge..$^{30,33}$

This study has several limitations. First, it is a retrospective study, so information related with the index admissions and readmissions might have been missing. Furthermore, it was a single institution study of a level II hospital, with a relatively small sample, and therefore the results may not be generalizable to the Portuguese pediatric population. This study did not consider patients readmitted to a different hospital, so the overall true readmission rate in this population is probably higher. Our hospital's pediatric emergency department has an observation area that admits patients from the emergency room who will predictably have a short length of stay (usually up to 48 hours), thus preventing an admission in the pediatric ward. In this study, we did not consider these patients, which might also have underestimated the overall readmission rate. Finally, our study did not attempt to compare patients with and without readmissions, which would have been essential to try to find risk factors for readmissions.

The general use of readmission rates as a quality measure of hospital care is still very controversial and even more so in the pediatric population. As such, a national multicenter prospective cohort study is crucial in order to better characterize pediatric readmissions, to assess their preventability and possible risk factors to ultimately understand how to better prevent them. The contributions of external factors such as the family's social and economic conditions, access to ambulatory care and social support in the community after discharge also warrant further study.

\section{CONCLUSION}

In our study, we found a low overall readmission rate, but a higher percentage of potentially preventable readmissions, when compared with the available literature. We also found that the patients assessed in the pediatric day hospital after discharge from the index admission, had significantly shorter times until readmission. When there was an underlying chronic disease, readmissions due to decompensation of chronic disease were considered more likely to be preventable. On the other hand, the existence of chronic disease and neurological impairment were identified as risk factors for multiple readmissions.

\section{AUTHORS CONTRIBUTION}

JSM: Design of the work, data acquisition, interpretation and management, draft of the paper.

RS: Design of the work, data acquisition, data management, draft of the paper.

JM, PC: Design of the work, critical review and major contribution for the final version of the paper.

\section{PROTECTION OF HUMANS AND ANIMALS}

The authors declare that the procedures were followed according to the regulations established by the Clinical Research and Ethics Committee and to the Helsinki Declaration of the World Medical Association updated in 2013.

\section{DATA CONFIDENTIALITY}

The authors declare having followed the protocols in use at their working center regarding patients' data 
publication.

\section{COMPETING INTERESTS}

The authors declare that no competing interests exist nor any form of support.

\section{REFERENCES}

1. Berry JG, Gay JC. Preventing readmissions in children: how do we do That? Hosp Pediatr. 2015;5:602-4.

2. Wallace SS, Quinonez RA. Solving the readmissions puzzle: how do variability and preventability fit? Pediatrics. 2017;140:e20171681.

3. Hain PD, Gay JC, Berutti TW, Whitney GM, Wang W, Saville BR. Preventability of early readmissions at a children's hospital. Pediatrics. 2013;131:e171-81.

4. Markham JL, Hall M, Gay JC, Bettenhausen JL, Berry JG. Length of stay and cost of pediatric readmissions. Pediatrics. 2018;141:e20172934.

5. Gay JC, Hain PD, Grantham JA, Saville BR. Epidemiology of 15-day readmissions to a children's hospital. Pediatrics. 2011;127:e1505-12.

6. Gay JC, Agrawal R, Auger KA, Del Beccaro MA, Eghtesady P, Fieldston $E S$, et al. Rates and impact of potentially preventable readmissions at children's hospitals. J Pediatr. 2015;166:613-9.

7. Berry JG, Toomey SL, Zaslavsky AM, Jha AK, Nakamura MM, Klein DJ, et al. Pediatric readmission prevalence and variability across hospitals. JAMA. 2012:23:372-80.

8. Toomey SL, Peltz A, Loren S, Tracy M, Williams K, Pengeroth L, et al. Potentially preventable 30-day hospital readmissions at a children's hospital. Pediatrics. 2016;138:e20154182.

9. Sousa-Pinto B, Gomes AR, Oliveira A, Ivo C, Costa G, Ramos J. Hospital readmissions in Portugal over the last decade. Acta Med Port. 2013;26:711-20.

10. Morse RB, Hall M, Fielston ES, Goodman DM, Berry JG, Gay JC, et al. Children's hospitals with shorter lengths of stay do not have higher readmission rates. J Pediatr. 2013;163:1034-8.

11. Joynt KE, Jha AK. Thirty-day readmissions - truth and consequences. N Engl J Med. 2012;366:1366-9.

12. Nakamura MM, Zaslavsky AM, Toomey SL, Petty CR, Bryant MC, Geanacopoulos AT, et al. Pediatric readmissions after hospitalizations for lower respiratory infections. Pediatrics. 2017;140:e20160938.

13. Lax $Y$, Martinez M, Brown NM. Social determinants of health and hospital readmission. Pediatrics. 2017;140:e20171427.

14. Feudtner C, Levin JE, Srivastava R, Goodman DM, Slonim AD, Sharma $V$, et al. How well can hospital readmission be predicted in a cohort of hospitalized children? A retrospective, multicenter study. Pediatrics. 2009;123:286-93.

15. Berry JG, Hall DE, Kuo DZ, Cohen E, Agrawal R, Feudtner C, et al. Hospital utilization and characteristics of patients experiencing recurrent readmissions within children's hospitals. JAMA. 2011;16:682-90.

16. Feudtner C, Pati S, Goodman D, Kahn MG, Sharma V, Hutto JH, et al. State-level child health system performance and the likelihood of readmission to children's hospitals. J Pediatr. 2010;157:98-102.

17. Feudtner C, Feinstein JA, Zhong W, Hall M, Dai D. Pediatric complex chronic conditions classification system version 2: updated for ICD-10 and complex medical technology dependence and transplantation. BMC Pediatr. 2014;14:1-7.

\section{FUNDING SOURCES}

This research received no specific grant from any funding agency in the public, commercial, or not-for-profit sectors.

18. Liz CF, Cardoso AL, Soares S, Lira S, Machado Â. Readmissões num serviço de urgência de pediatria. Braga: Associação Pediátrica do Minho; 2018

19. Ferraz C, Vaz R, Azevedo M, Carvalho I, Santos LA. Readmissões na urgência pediátrica do Porto. Arq Med. 2009;23:173-5.

20. Lemos L. Readmissões não-previstas no serviço de urgência, após alta das unidades de internamento de curta duração. Saúde Infantil. 1998;20:5-17.

21. Sills MR, Hall M, Cutler G, Colvin JD, Gottlieb LM, Macy ML, et al. Adding social determinant data changes children's hospitals' readmissions performance. J Pediatr. 2017;186:150-7.

22. Pérez-Moreno J, Leal-Barcelóa AM, Isidroa EM, Del Castillo BT, Golzález-Martínez F, Rodríguez-Fernándeza R. Detection of risk factors for preventable paediatric hospital readmissions. Anal Pediatr. 2019;91:365-70.

23. Wallace SS, Keller SL, Falco CN, Nead JA, Minard CG, Nag PK, et al An examination of physician-, caregiver-, and disease-related factors associated with readmission from a pediatric hospital medicine service. Hosp Pediatr. 2015;5:566-73.

24. Clarke A. Readmission to hospital: a measure of quality or outcome? Qual Saf Health Care. 2014;13:10-1.

25. Jordão $\mathrm{E}$. A problemática dos reinternamentos: análise comparativa dos serviços de medicina das duas unidades do Centro Hospital do Alto Ave EPE. Braga: Universidade do Minho; 2012

26. Kangovi S, Grande D. Hospital readmissions - not just a measure of quality. JAMA. 2011;306:1796-7.

27. Nakamura MM, Toomey SL, Zaslavky AM, Berry JG, Lorch SA, Jha AK, et al. Measuring pediatric hospital readmission rates to drive quality improvement. Acad Pediatr. 2014;14:S39-46.

28. Srivastava R, Keren R. Pediatric readmissions as a hospital quality measure. JAMA. 2013;309:396-8.

29. Auger KA, Simon TD, Cooperberg D, Kuo DZ, Saysana M, Stille CJ, et al. Summary of STARNet: seamless transitions and (re)admissions network. Pediatrics. 2015;135:164-75.

30. Auger KA, Kenyon CC, Feudtner C, Davis MM. Pediatric hospital discharge interventions to reduce subsequent utilization: a systematic review. J Hosp Med. 2014;9:251-60.

31. Berry JG, Ziniel SI, Freeman L, Kaplan W, Antonelli R, Gay J, et al. Hospital readmission and parent perceptions of their child's hospital discharge. Int J Qual Health Care. 2013;25:573-81.

32. Brittan M, Albright K, Cifuentes M, Jimenez-Zambrano A, Kempe A. Parent and provider perspectives on pediatric readmissions: what can we learn about readiness for discharge? Hosp Pediatr. 2015:5:559-65.

33. Berry JG, Blaine K, Rogers J, McBride S, Schor E, Birmingham J, et al. A framework of pediatric hospital discharge care informed by legislation, research, and practice. JAMA Pediatr. 2014;168:955-62. 